\title{
In Ukraine, mistrust of doctors remains high
}

$\mathrm{D}$ r. Richard Styles was used to being trusted as a doctor in Britain, but that changed when he moved to Ukraine a decade ago, after working in a number of European Union-funded projects there.

"There is nearly no trust in doctors at all, even amongst doctors," says the chief medical director at the American Medical Centre in Kyiv, Ukraine's capital.

Indeed, a 2015 report by European Observatory on Health Systems and Policies, a partnership led by the World Health Organization (WHO), found that "popular mistrust of doctors [in Ukraine] is strikingly high," and has been for many years.

Dr. Zoryana Chernenko, an assistant professor at the National University of Kyiv Mohyla Academy, points to Ukraine's chronically low wages for doctors as one of the main culprits. This has forced doctors to supplement their incomes with informal out-of-pocket payments, despite the system supposedly being free at the point of service.

"Every day, doctors are just thinking about how to survive," said Chernenko, who has worked on health system reform in Ukraine.

Wages for doctors in Ukraine have been low since before the 2014 Euromaidan Revolution, a series of violent events culminating in the ousting of the president. According to the European Observatory's report, in 2013 the average monthly wage for a doctor in Ukraine was just over $\$ 400$ a month, well behind that of professionals in many sectors of Ukraine's economy.

More recent data on doctors' wages in the Ukraine are not available, but an analysis published in October by the Ukrainian newspaper Komsomolskaya Pravda suggested that the average wage had fallen to less than $\$ 260$ by mid-2015. Given that Ukraine's currency has lost almost $20 \%$ of its value since the beginning of 2016, doctors' wages are likely to drop even further.

Out-of-pocket payments have been a regular feature of Ukraine's health

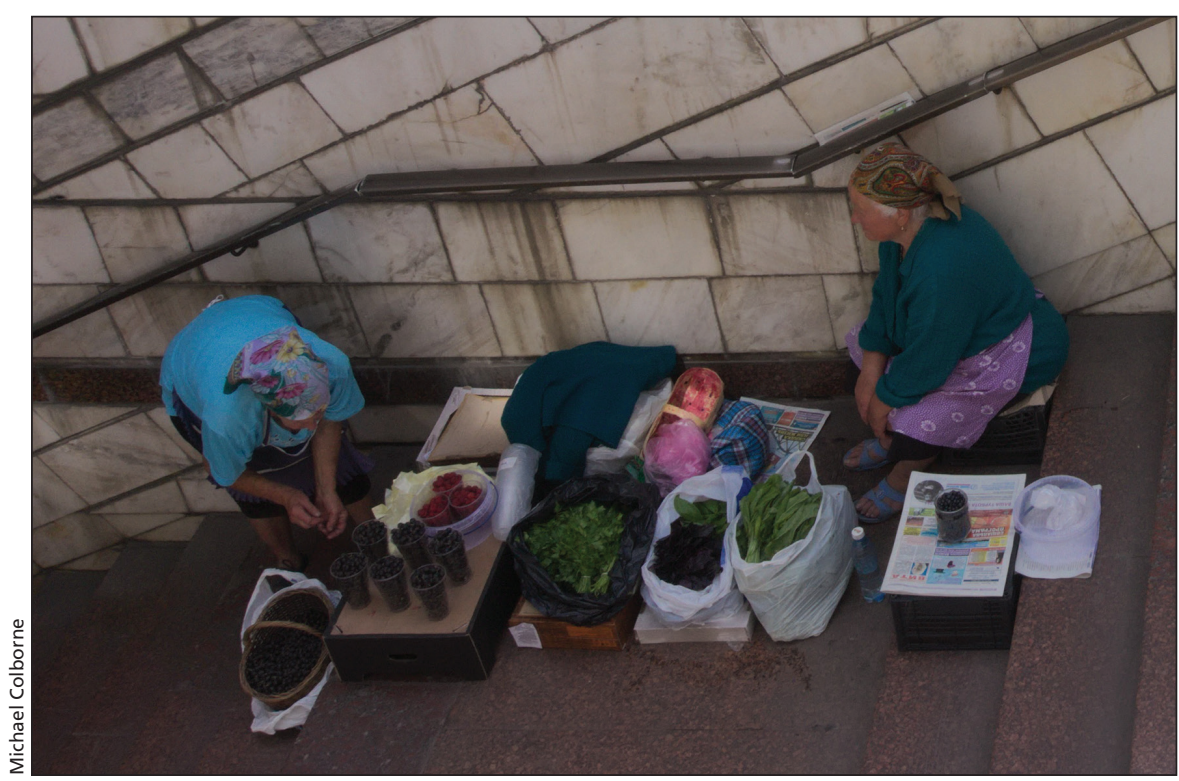

Ukraine's economy has experienced a substantial downturn since the Soviet Union was dissolved, with people, including physicians who earn $\$ 265 /$ month, making money however they can.

care system since the 1990s following the collapse of the Soviet Union, according to the European Observatory's report. During the subsequent severe economic downturn, doctors began levying informal payments to provide themselves with a more acceptable wage. Chronic government underfunding - including a 5\% cut to health spending in 2016 - has contributed to these payments becoming an entrenched feature of the Ukraine's health system.

"At the moment state funding covers only half of the financial needs of the system," Konstantin Nadutyi, deputy chairman of the Ukrainian Medical Association, recently told The Lancet in a Feb. 20, 2016 article. "The rest is paid for by patients themselves."

Patients in Ukraine usually give informal payments before a service is given. Sometimes these payments provide them with quicker access, other times with newer drugs and services.

This system of soliciting informal out-of-pocket payments, according to Chernenko, has led to Ukrainians feeling like their doctors are more con- cerned with their bottom lines than providing quality care.

This system of low wages and informal payments has also led to chronic overtreatment, which further erodes trust in doctors, says Styles.

"The problem is that people [in Ukraine] don't get value for money." Styles estimates that a substantial portion of Kyiv's three million people is overtreated and prescribed drugs or forced to pay for services they do not need. "It's rather strange in a health care budget that's got its back to the wall."

However, Styles is keen to point out that many of the Ukraine's doctors, despite how they might be perceived, are hardworking, dedicated professionals. "I would be very careful not to denigrate Ukrainian doctors," he stresses, pointing out the number of doctors who have risked life and limb in war-torn eastern Ukraine.

"In Ukraine, there are some very dedicated, very vocational doctors who are working for nearly nothing." Michael Colborne, Edmonton, Alta. 